http://nv.nltu.edu.ua

https://doi.org/10.15421/40290415

Article received $12.03 .2019 \mathrm{p}$.

$@ \bowtie$ Correspondence author

Article accepted 25.04.2019 p.

Yu. V. Muraviov

УДК 639.1.052-0.47.37(477.83)

muravjov@i.ua

Ю. В. Муравйов

Національний лісотехнічний університет Украӥни, м. Львів, Украӥна

\title{
ДОСЛІДЖЕННЯ РОЗПОДІЛУ МИСЛИВСЬКИХ УГІДЬ ЛЬВІВСЬКОЇ ОБЛАСТІ
}

\begin{abstract}
Мисливське господарство залишається однією із неприбуткових галузей національного господарства. Передусім залишається невирішеним питання щодо ефективного користування мисливськими угіддями. Мисливське господарство України потребує реформування та дієвих стратегічних кроків, які базувалися б на засадах Сталого розвитку. На основі актуальних статистичних даних проаналізовано розподіл мисливських угідь Львівської області між користувачами на 31.01.2017. Порівняно сучасний розподіл площ мисливських угідь з розподілом на 01.01.2016. Досліджено зміни кількісного складу мисливських угідь та їх користувачів. Досліджено зміни площ угідь Львівської області за аналізований період. Виявлено проблеми, що стосуються користування мисливськими угіддями. Здійснено аналіз нормативно-правової бази щодо мисливського господарства України. Розглянуто досвід європейських країн у галузі мисливського господарства. Виявлено недоліки у законодавстві мисливської галузі, зокрема недосконалість системи відповідальності за порушення цього законодавства. Відсутні чіткі норми та порядок надання мисливських угідь в користування. Законодавчі акти потребують змін для забезпечення ефективного користування мисливськими угіддями. Запропоновано шляхи для покращення управління мисливськими угіддями. Рекомендовано у найближчому майбутньому провести інвентаризацію ресурсів мисливських угідь. Вкрай нагальним завданням $€$ удосконалення нормативно-правової бази діяльності та перспектив розвитку мисливського господарства України.

Ключові слова: мисливське господарство; користувачі мисливських угідь; структура мисливських угідь; динаміка обсягів мисливських угідь.
\end{abstract}

Вступ. На сьогодні необхідною умовою успішного функціонування економіки України $є$ дотримання принципів Сталого розвитку у кожній галузі країни. Мисливське господарство, як вагома складова частина лісового сектору України, не $\epsilon$ винятком. Попри сприятливі природні умови на території нашої держави, мисливське господарство залишається збитковою галуззю та потребує ефективних заходів (Deyneka \& Burmas, 2013; Ivanusa \& Holyavka, 2011).

Основною проблемою мисливського господарства України є недосконалість нормативно-правової бази щодо конкретної схеми при наданні у користування мисливських угідь, плати за користування ними та відшкодування завданих збитків (Zakon Ukrainy, 2000; Muraviov \& Hoetskiy, 2011). Відсутність чіткості у зазначених вище процесах $\epsilon$ вигідною для сприяння розвитку різноманітних корупційних схем у мисливському господарстві нашої країни (Ivanusa \& Holyavka, 2011; Muraviov \& Hoetskiy, 2011).

Механізм надання у користування мисливських угідь в Україні $\epsilon$ надзвичайно складним і довготривалим процесом. Для прийняття рішення обласною радою потрібне подання Державного агентства лісових ресурсів України, яке має бути погодженим обласними держадміністраціями, управліннями охорони навколишнього природного середовища та власниками чи користувачами земельних ділянок (Zakon Ukrainy, 2000; Protsiv, 2016). До прикладу, у Словаччині аналогічне pi- шення приймає керівник районного лісового управління за умови погодження $2 / 3$ власників земельних ділянок, а в Угорщині мисливські угіддя надаються у користування управліннями лісового господарства (Protsiv, 2016).

Дослідження розподілу та використання мисливських угідь $є$ передумовою створення стратегії вдосконалення мисливського господарства, яке опиралося 6 на принципи сталості (невиснажливості, далекоглядності).

Мета дослідження - з'ясувати та проаналізувати наявні зміни у розподілі лісомисливських угідь Львівської області.

Об'єкт дослідження - мисливські угіддя Львівської області.

Методи дослідження - порівняльний аналіз та математична статистика.

Результати дослідження та обговорення. Людська спільнота дедалі більше усвідомлює той факт, що довкілля має не тільки ресурсне значення, але є невід'ємним компонентом його існування. Особливо нагально проблема раціонального використання ресурсів природи повстала наприкінці XX - початку XXI ст. Це пов'язано зі шаленим розвитком науково-технічного прогресу, невід'ємною складовою частиною якого завжди є ресурси природи.

Незважаючи на зусилля свідомого суспільства, стабілізувати навколишнє природне середовище, яке дедалі інтенсивніше деградує під впливом деструктивної

Інформація про авторів:

Муравйов Юрій Володимирович, канд. екон. наук, доцент, кафедра менеджменту організацій і адміністрування.

Email: muravjov@i.ua

Цитування за ДСту: Муравйов Ю. В. Дослідження розподілу мисливських угідь Львівської області. Науковий вісник Нлту України. 2019, т. 29, № 4. С. 72-74.

Citation APA: Muraviov, Yu. V. (2019). Research of distribution of hunting grounds of the Lviv region. Scientific Bulletin of UNFU, 29(4), 72-74. https://doi.org/10.15421/40290415 
виробничо-господарської діяльності, не вдалося змінити ситуацію на краще. У складі відновлювальних природних ресурсів особливе місце займають лісові, оскільки вони істотно впливають на економічний, соціальний і культурний розвиток людства. 3 одного боку, це запаси цінної природно відновлюваної сировини, 3 іншого - важливий чинник стабільності довкілля.

Невід'ємною та рівноцінною складовою частиною лісового середовища є лісові мисливські угіддя. Вони створюють необхідні умови для проживання ресурсів мисливських тварин, забезпечуючи їх кормами, захистом, умовами для розмноження. Роль людини полягає у розумному втручанні у ці процеси із врахуванням екологічного, соціального та економічного складників.

Зазначені вище процеси та складники впливу людського чиннику на ресурси мисливських угідь будуть значно активніші за умови, що буде вивчено їх стан у розрізі користувачів та власників. Мисливські угіддя України $є$ досить різноманітні та мають потужний потенціал з нарощування еколого-економічної та соціальної ефективності їх використання.

На 31.01.2017 р. загальна площа мисливських угідь Львівської обл. становить 1 млн 628 тис. га, що майже на $3 \%$ більше, ніж на 01.01.2016 р. (1 млн 586 тис. га). Площа перелічених у таблиці мисливських угідь становить 74,6 \% від загальної площі Львівської обл. Усі мисливські угіддя розподілені між 79 користувачами (Mislivske gospodarstvo, 2017).

На території Львівської обл. можна виділити сім груп користувачів мисливських угідь, серед яких 15 мисливських господарств обласної організації УТМР, 10 мисливських господарств ТМіР "Лісівник", 15 підприємств, які належать до складу Львівського обласного управління лісового та мисливського господарства (ЛОУЛМГ), серед них НПП "Сколівські Бескиди", Одне мисливське господарство, що належить до Військового товариства ВМТ ЗРУ, два мисливських господарства ФСТ "Динамо", 12 господарств, що належать до громадських організацій, та 24 господарства інших форм власності (Mislivske gospodarstvo, 2017).

Можемо стверджувати, що в мисливських угіддях Львівської обл. не спостерігається державне монопольне право. Разом з тим, на нашу думку, розподіл площ мисливських угідь Львівської обл. за користувачами $\epsilon$ завеликими і нерівномірними. Змінюється цей розподіл від 3208 га у Бродівській p/p УТМР (згідно з нормами законодавства 3000 га) до 74652 га у Радехівському ТМіР. Такий стан справ потребує диференційованого підходу до ведення мисливського господарства, охорони та відтворення як ресурсів мисливських угідь та тварин, величини капіталовкладень та поточних витрат, кількості кваліфікованого персоналу та фондоозброєності. Недотримання таких вимог призводить до того, що користувачі мисливських угідь, через певні об'єктивні та суб'єктивні чинники, тільки експлуатують мисливські угіддя.

Корисним є приклад Польщі, де всі мисливські угіддя розділені на господарства, паспортизовані, мають єдину загальнодержавну нумерацію. Для чіткої процедури надання мисливських угідь Польщі у користування та сплати державного податку, всі межі цих угідь введено до баз даних GIS (Delehan \& Shpilchak, 2008). Відсоткове співвідношення площ мисливських угідь між користувачами зображено на рис. 1 .

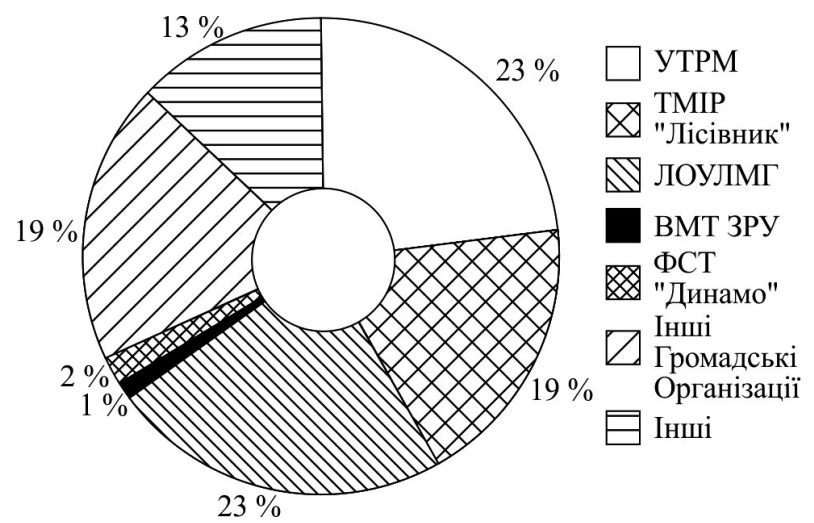

Рис. 1. Співвідношення площ мисливських угідь (\%) Львівської області між користувачами на 31.01 .2017 p.

Згідно 3 рис. 1 можемо зробити висновок, що найбільша частина мисливських угідь (близько 23 \%) надана у користування підприємствам Львівського обласного управління лісового та мисливського господарства та мисливським господарствам обласної організації УТМР.

На 01.01.2016 у Львівській обл. налічувалося 74 користувачі мисливських угідь на площі 1 млн 586 тис. га. Серед них 15 підприємств ЛОУЛМГ (371 тис. га), 14 організацій УТМР (387 тис. га), 10 товариств ЛОТМІP "Лісівник" (302 тис. га), одне мисливське господарство ТВМР ЗРУ (21 тис. га), два господарства ФСТ "Динамо" (30 тис. га), 10 інших громадських мисливських об'єднань (239 тис. га) та 22 мисливських організацій різної форми власності (200 тис. га) (Mislivske gospodarstvo, 2017). Розподіл мисливських угідь на 01.01.2016 р. зображено на рис. 2.

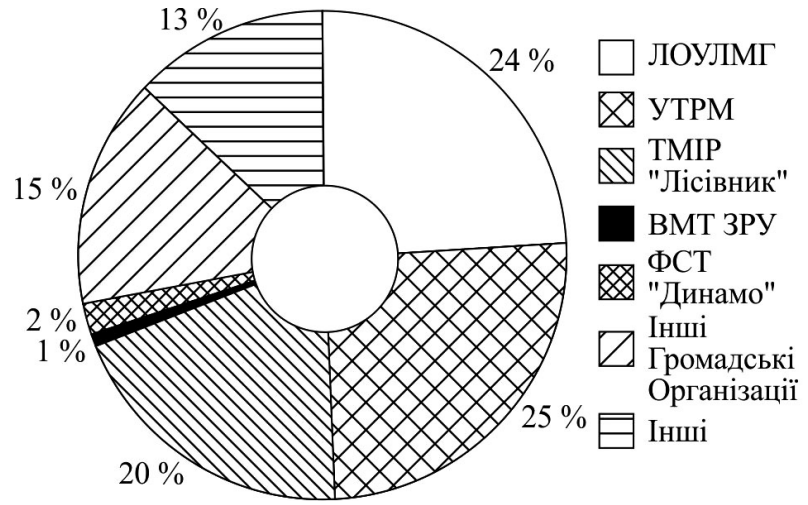

Рис. 2. Співвідношення площ мисливських угідь (\%) Львівської області між користувачами на 01.01.2016 p.

Аналізуючи рис. 1 і 2, можемо стверджувати, що розподіл між користувачами мисливських угідь упродовж 2016-2017 pp. істотно не змінився. Зокрема, на 31.01.2017 р. частка угідь ЛОУЛМГ та частка угідь УТМР зрівнялася і становить $23 \%$, що відповідно на 1 та на $2 \%$ менше, ніж за попередній рік, а частка інших громадських організацій зросла на 4 \%. Такі структурні зміни спричинені як загальним збільшенням всієї площі мисливських угідь Львівської обл. майже на 3 \% (станом на 31.01.2017), так і зменшенням чи збільшенням сумарної величини площ угідь у підпорядкування кожного користувача.

Висновки. Львівська обл. потребує нарощування ресурсного потенціалу мисливських угідь та розроблення критеріїв ефективного користування ними. Зміни у загальній площі та розподілі мисливських угідь Львівської обл. за аналізований період $\epsilon$ незначними. 
Кількість користувачів збільшилася від 74 до 79 користувачів. На 31.01.2017 р. найбільші частки мисливських угідь (близько $23 \%$ ) є у користуванні підприємств Львівського обласного управління лісового та мисливського господарства та мисливських господарство обласної організації УТМР.

Доцільно не збільшувати щороку площі угідь та кількість користувачів, а переглянути нормативно-правову базу ведення мисливського господарства для впровадження суворіших обмежень щодо розподілу, користування, охорони та відтворення ресурсів мисливських угідь та тварин.

Пропонуємо провести інвентаризацію мисливських угідь. Потрібно створити банк даних про користувачів мисливських угідь та посилити їх відповідальність за недотримання мисливського законодавства.

Вважаємо, що найконструктивнішим рішенням для забезпечення сталого ведення мисливського господарства $€$ внесення чіткого механізму у законодавство щодо визначення плати за користування ресурсами мис- ливських угідь, що трунтувався б на бонітуванні, типології та класифікації мисливських угідь.

\section{Перелік використаних джерел}

Delehan, I., \& Shpilchak, M. (2008). Features of hunting management in Poland. Scientific Bulletin of UNFU, 18(9), 42-47. [In Ukrainian].

Deyneka, A., \& Burmas, V. (2013). State and prospects of hunting economy development. Scientific Bulletin of UNFU, 23(13), 78-94. [In Ukrainian].

Ivanusa, A., \& Holyavka, V. (2011). Analysis of hunting management by enterprises of Lviv region. Scientific Bulletin of UNFU, 21(18), 108-112. [In Ukrainian].

Mislivske gospodarstvo. (2017). Rozpodil myslyvskykh uhid Lvivskoi oblasti. Retrieved from: https://lvivlis.gov.ua/hunting. [In Ukrainian].

Muraviov, Y., \& Hoetskiy, P. (2011). Analysis of hunting management and ways to increase its efficiency. Scientific Bulletin of $U N$ FU, 21(1), 23-29. [In Ukrainian].

Protsiv, O. (2016). Foreign assistance and experience in hunting economy service. Poliuvannia ta rybolovlia, 10(180), 2. [In Ukrainian].

Zakon Ukrainy. (2000). "Pro myslyvske hospodarstvo ta poliuvannia" vid 22.02.2000 r., № 1478-III. Retrieved from: https://zakon.rada. gov.ua/laws/show/1478-14. [In Ukrainian].

Yu. V. Muraviov

Ukrainian National Forestry University, Lviv, Ukraine

\section{RESEARCH OF DISTRIBUTION OF HUNTING GROUNDS OF THE LVIV REGION}

The main problem of the hunting economy of Ukraine is the imperfection of the legal and regulatory framework for a specific scheme for the provision of hunting grounds for use, fees for their use and compensation for losses incurred. Hunting remains one of the non-profit sectors of the national economy. First of all, the issue of effective use of hunting grounds remains unresolved. Hunting of Ukraine needs reformation and effective strategic steps that would be based on the principles of sustainable development. On the basis of topical statistical data, the distribution of hunting grounds of Lviv Region among users was analysed as of 31. 01. 2017. The actual distribution of hunting grounds is compared with the distribution of lands as of 01.01.2016. Changes in the quantitative composition of hunting grounds and their users are investigated. Changes in the areas of Lviv Region lands for the analysed period were researched. The problems related to the use of hunting grounds are revealed. The analysis of the regulatory framework on hunting economy of Ukraine was carried out. The experience of European countries in the field of hunting economy is considered. The flaws in the legislation of the hunting industry are revealed, in particular, the absence of a system of liability for violation of this legislation. There are no clear norms and procedures for the provision of hunting grounds for use. Therefore, there is a need to increase the resource potential of hunting grounds and develop criteria for their effective use in Lviv Region. Changes in the total area and distribution of hunting grounds in the Lviv Region for the analysed period are insignificant. The number of users has increased from 74 to 79. An annual increase in the area of hunting grounds is inappropriate. The inventory of hunting grounds is recommended to be performed. Legislative acts require changes to ensure effective use of hunting grounds. The ways of improvement of hunting grounds management are offered. An effective solution for improving hunting management is a clear mechanism for determining the fee for the use of hunting grounds based on the typology and classification of hunting grounds.

Keywords: hunting; hunting grounds users; hunting ground structure; dynamics of volumes of hunting grounds. 